\title{
Possible hazardous effects of hydrofluoric acid and recommendations for treatment approach: a review
}

\author{
Özcan, M ; Allahbeickaraghi, A ; Dündar, M
}

\begin{abstract}
Hydrofluoric acid (HF) is commonly used for conditioning the glass ceramics either prior to cementation or for intraoral repair in prosthetic and restorative dentistry. The present study offers a review of chemical properties of HF used, highlight the possible hazardous effects of this agent, and to recommend the treatment approach for potential risks. Available published information documented in PubMed, Medline, and Picarta literature databases was reviewed. Additional information was derived from scientific reports, medical and chemical textbooks, handbooks, product information, manufacturers' instructions, Internet web sites of the HF manufacturers. No report was found on the incidence of the hazardous effects of HF in dentistry. Reports from other fields presented incidences of acute and chronic symptoms in exposure to HF. While acute symptoms include skin or nail burns, chronic ones involve systemic toxicity, eye injuries, inhalation and ingestion-related symptoms that can be even fatal. HF can be harmful and particularly aggressive to soft tissues, but symptoms may not be apparent immediately after exposure. The hazardous effects are not based on the $\mathrm{pH}$ value, but on the toxicity of HF. Potential hazards of HF known from other applications than dentistry should be considered also in dental applications. Especially the clinicians, who often deal with adhesive cementation or repair of glass ceramics, should take necessary precautions for possible hazards of HF.
\end{abstract}

DOI: https://doi.org/10.1007/s00784-011-0636-6

Posted at the Zurich Open Repository and Archive, University of Zurich

ZORA URL: https://doi.org/10.5167/uzh-62951

Journal Article

Published Version

Originally published at:

Özcan, M; Allahbeickaraghi, A; Dündar, M (2012). Possible hazardous effects of hydrofluoric acid and recommendations for treatment approach: a review. Clinical Oral Investigations, 16(1):15-23.

DOI: https://doi.org/10.1007/s00784-011-0636-6 


\title{
Possible hazardous effects of hydrofluoric acid and recommendations for treatment approach: a review
}

\author{
Mutlu Özcan • Arezo Allahbeickaraghi • Mine Dündar
}

Received: 2 September 2010 / Accepted: 26 October 2011 /Published online: 9 November 2011

(C) Springer-Verlag 2011

\begin{abstract}
Hydrofluoric acid (HF) is commonly used for conditioning the glass ceramics either prior to cementation or for intraoral repair in prosthetic and restorative dentistry. The present study offers a review of chemical properties of HF used, highlight the possible hazardous effects of this agent, and to recommend the treatment approach for potential risks. Available published information documented in PubMed, Medline, and Picarta literature databases was reviewed. Additional information was derived from scientific reports, medical and chemical textbooks, handbooks, product information, manufacturers' instructions, Internet web sites of the HF manufacturers. No report was found on the incidence of the hazardous effects of HF in dentistry. Reports from other fields presented incidences of acute and chronic symptoms in exposure to HF. While acute symptoms include skin or nail burns, chronic ones involve systemic toxicity, eye injuries, inhalation and ingestion-related symptoms that can be even fatal. HF can be harmful and particularly aggressive to soft tissues, but symptoms may not be apparent immediately after exposure. The hazardous effects are not based on the $\mathrm{pH}$
\end{abstract}

M. Özcan $(\bowtie)$

University of Zürich, Dental Materials Unit,

Center for Dental and Oral Medicine, Clinic for Fixed

and Removable Prosthodontics and Dental Materials Science,

Plattenstrasse 11,

CH-8032 Zurich, Switzerland

e-mail: mutluozcan@hotmail.com

A. Allahbeickaraghi

Dental School, University of Groningen,

Antonius Deusinglaan 1,

9713 AV Groningen, The Netherlands

M. Dündar

Department of Prosthodontics, School of Dentistry,

Ege University,

35100 Izmir, Turkey value, but on the toxicity of HF. Potential hazards of HF known from other applications than dentistry should be considered also in dental applications. Especially the clinicians, who often deal with adhesive cementation or repair of glass ceramics, should take necessary precautions for possible hazards of HF.

Keywords Dental ceramics · Dentistry $\cdot$ Hazardous compounds · Hydrofluoric acid

\section{Introduction}

Highly concentrated, pure aqueous solution of hydrofluoric acid (HF) was first prepared in 1809 and hydrogen fluoride was first obtained at the end of the eighteenth century [1, 2]. From chemistry perspective, HF is the inorganic acid of elemental fluorine. Hydrogen fluoride is produced by the reaction of calcium fluoride $\left(\mathrm{CaF}_{2}\right)$ and sulfuric acid in a reaction furnace at $200^{\circ} \mathrm{C}$, which is then cooled and stored as a colorless liquid $[1,2]$. The main source of $\mathrm{CaF}_{2}$ to produce hydrogen fluoride is the mineral fluorspar. The volatile HF is condensed and purified by distillation $[1,2]$. HF can be produced through processes such as aluminum melting, ceramic production, and phosphate fertilizers. It may also occur as an impurity in different chemicals or can be produced through the reaction of other chemicals [1]. It is the starting material for the production of most organic and inorganic chemicals containing the fluorine atom. Fluorine gas is the most important fluorine compound for industrial use.

HF solutions can be formed when fluoride salts are acidified with acidic solutions. As it is a weak acid, hydrogen fluoride in water for instance, is not completely ionized. Its conjugate base, the fluoride ion $\mathrm{F}^{-}$, can reassociate to form $\mathrm{HF}$ in solutions with low $\mathrm{pH}$ [3]. In strong 
acidic solutions, the $\mathrm{pH}$ of the fluoride-containing mixture will be low and the free $\mathrm{F}^{-}$formed from the ionization of the fluoride salt in aqueous solution will exist as HF. However, in acidic aqueous suspensions, solubility increases by the presence of the acid, and with this route a significant quantity of HF can be produced [1].

Early versions of HF were aqueous solutions. Aqueous HF is commonly formulated for products with lower concentration. The major use of aqueous HF for occupational purposes are etching and polishing glass and ceramics, removing sand from metal castings, and cleaning processes for floors and walls [3]. Other important uses include fabric rust removal, etching silicon in semiconductors, cleaning stone and marble, and manufacturing inorganic fluoride compounds $[4,5]$.

Since the introduction of glass-based ceramics and discovery of the benefits of adhesive cementation in dentistry, HF started to be used to condition restorative and prosthetic devices [6]. Strong bonds are formed between resin-based materials and dental ceramics that are etched with HF [7]. This is based on the affinity of fluoride to silicon that is higher than to oxygen: $4 \mathrm{HF}+\mathrm{SiO}_{2} \rightarrow \mathrm{SiF}_{4}+2 \mathrm{H}_{2} \mathrm{O}$. By the selective removal of the glassy matrix, principally micromechanical retention is achieved between the resin and the etched ceramic. The greatest advantage of the use of HF for ceramics is that its chair-side application is very simple, and for this reason, sophisticated conditioning or cleaning methods may not be necessary [8].

In 1998, in fields other than dentistry, HF was acknowledged as a highly hazardous chemical due to its toxicity, corrosiveness, and reactivity [1]. It can be used in the anhydrous $(100 \%)$ form or in aqueous solutions where the latter range in concentration from $<1-70 \%$. Severity and rapidity of onset of signs and symptoms depends on the concentration, duration of exposure, and penetration to the exposed tissue [6]. When accidentally released, HF can diffuse as a dense vapor and aerosol. HF itself is not flammable, explosive, or oxidizing, but it is a highly reactive chemical. Hence, its storage conditions and handling must be taken into account when using this acid. Also, contact with metals can lead to the formation of hydrogen gas, which forms explosive mixtures in air at concentrations between $4 \%$ and $75 \%[1,2]$. The reaction occurs at concentrations of approximately less than $65 \%$ of aqueous HF but over time at higher concentrations of anhydrous HF. In closed containers, hydrogen formation can cause dangerously high pressures $[9,10]$. As the reaction of hydrogen fluoride or concentrated HF with water is exothermic, it may react violently on mixing. Concentrated aqueous solutions can fume in the air, and heat is produced upon reaction.

The objective of this review was to summarize the chemical properties, applications of HF used in medical or other fields as well as in restorative and prosthetic dentistry, to investigate the incidence of reports on hazardous effects of $\mathrm{HF}$ in dentistry, to highlight the possible hazardous effects of this agent in general, and to recommend the treatment approach for potential risks, based on the published information available in the chemical and medical fields.

\section{Materials and methods}

Original scientific papers listed in PubMed, Medline, Picarta up to the end of 2010 on HF were included in this review using the following search terms: hydrofluoric acid, acid etching, surface conditioning, ceramics, fracture, repair, hydrofluoric acid burns, hydrofluoric acid treatment, hydrofluoric acid etching, workplace poisoning, poisoning, fatalities, cementation, ceramics, intra-oral repair, fluorohydric acid, fluoric acid, and hydrogen fluoride solution. Only articles in English were selected. Additional information was derived from scientific reports, medical and chemical textbooks, handbooks, product information, manufacturers' instructions, Internet web sites of the HF manufacturers.

\section{Results}

While no reports of incidence have been found on the hazardous effects due to exposure to HF in the dental literature, low incidence of reactions or even death presented as case reports have been reported in the case of significant or long exposure to HF in other fields. Potential hazards in case of significant exposure and the therapy approach to each of the symptom could be summarized as follows.

\section{Acute hazardous effects}

As with all inorganic acids, due to hydrogen ion degeneration and corrosion, HF can burn the skin [11-13]. After penetrating into the skin, it moves quickly to the deeper tissue layers and releases the freely dissociable fluoride ion. Toxicity of this ion is based on its strong reactivity. The mechanism of HF injury is thought to be binding of fluoride ions to tissue calcium and magnesium cations to form insoluble salt. These interfere with cellular metabolism, inducing cellular death and necrosis [4]. HF burns could be as a consequence of the dehydrating effect of this agent and the low $\mathrm{pH}$. Skin contact with $\mathrm{HF}$, even dilute solutions $(0.1 \%)$ can cause painful second- and third-degree burns that heal very slowly [10]. Burns have a rather characteristic appearance and present as severely reddened, swollen areas with blanched, whitish regions that rapidly progress to blistering, and necrosis accompanied with pain [14]. Latent damages could also be observed since fluoride ion penetrates through all layers of 
the epidermis, dermis, and even the deeper subcutaneous tissues, causing severe destruction, necrosis, and injuries to the underlying bone due to decalcification [15]. The effect can continue for several days, causing increased tissue damage at a later stage. The damage is directly related to the concentration of the acid and the duration of contact. HF burns are classified according to the acid concentrations of 0 $20 \%, 21-50 \%$, and greater than $50 \%$ [15-19]. Skin contact with hydrogen fluoride, or solutions containing more than $50 \% \mathrm{HF}$, produces immediate pain. Reactions to more dilute solutions (concentration 20-50\%) may be delayed for minutes to several hours. The accompanying pain is excruciating and persistent, and healing is delayed [15-19]. Erythema and pain may be delayed up to $24 \mathrm{~h}$ in exposure to dilute HF solutions $(<20 \%)$.

Different types of therapy options have been suggested for HF burns. The aim of all treatment methods is to chemically sequester the fluoride ion and to prevent extensive, deep tissue destruction [20]. The first treatment of chemical burns should always be thorough and copious lavage of the wound to clean the unreacted surface chemical and dilute that is already in contact with the skin [20]. The second phase of the treatment aims to inactivate the free fluoride ion by promoting the formation of an insoluble fluoride salt. It was reported that the calcium ion could decrease the toxic effects of sodium fluoride in tissue [20,21]. For this reason, calcium gluconate gel $(2.5 \%)$ is widely used for first aid and/or primary treatment of skin burns due to exposure to HF [2230]. The gel is applied promptly and repeatedly onto the burned area, up to several hours. Using this gel may be more convenient for dilute acid burns that occur in exposure to commercial products such rust removers, aluminum cleaners using etching solutions [28]. If good relief of pain is not obtained after 30-40 min, alternative methods of treatment such as calcium gluconate injections or benzalkonium chloride soaks should be considered. Calcium gluconate injection (5\%) is indicated for large burns (over $160 \mathrm{~cm}^{2}$ ) or in cases where initial treatment has been delayed [31-34].

Burns of the fingers and nails permit penetration of fluoride ions but prevent gels from being effective. Therefore, it may be necessary to drill, split, or even remove nails to allow the topical treatment methods to be effective. However, it was reported that in less than $10 \%$ of the burns, removal of the nail was necessary [31-34]. If burned nail is immersed in benzalkonium chloride (Zephrian ${ }^{\circledR}$ ) solution immediately, it may be possible to avoid removing the nail.

Early aggressive surgery with primary excision of necrotic skin areas has also been recommended as an emergency measure to prevent deep tissue destruction and systemic absorption of fluoride ions [35-41]. When painful indolent ulcer remains resistant to all conservative measures, surgery may be considered with the possibility of unacceptable cosmetic results.
Chronic hazardous effects

HF is not classified as a carcinogen agent since no data exists supporting this. However, increased rates of cancer have been observed in workers exposed to a mixture of chemicals that included fluoride, but no single chemical was identified and reported as the cause of the cancer [13]. Yet, possible effects on reproduction have been postulated [42]. Studies on women exposed to fluoride for occupational reasons showed increased rates of menstrual irregularities. Animal studies also showed that fluoride impairs reproduction and increases fetal bone and teeth malformation [43].

\section{Systemic toxicity}

In case of severe inhalation or ingestion of HF, systemic toxicity is of concern.

To produce $\mathrm{HF}, \mathrm{CaF}_{2}$ reacts with sulfuric acid:

$$
\begin{aligned}
& \mathrm{CaF}_{2}+\mathrm{H}_{2} \mathrm{SO}_{4} \rightarrow 2 \mathrm{HF}+\mathrm{CaSO}_{4} \\
& 2 \mathrm{HF}+\mathrm{Ca}^{++} \rightarrow \mathrm{CaF}_{2}
\end{aligned}
$$

This process releases energy and occurs very quickly. Although the $\mathrm{pH}$ value of $\mathrm{HF}$ is only 3.45 , HF is soluble in water by a strong reaction at every concentration. Since it is very hygroscopic, it has the ability to dehydrate substances. Hence, it can quickly penetrate into skin and other soft tissues. When HF is exposed in concentrations of about $5 \%$ to human skin, initially, in most cases, no pain or other symptoms can be observed, but after several hours, a painful burn reaction may become apparent [44-48]. There is some evidence that when fluoride combines with calcium and phosphate, intracellular levels increase [2, 44]. Binding of fluoride to body calcium is one of the mechanisms of $\mathrm{HF}$ toxicity [47-52]. One serious consequence of exposure to $\mathrm{HF}$ is the decrease in serum calcium (hypocalcemia) and other metabolic changes, which may result in a fatal outcome if not recognized and treated [53-56]. Hypocalcemia should be considered as a potential risk in all instances of inhalation or ingestion, especially when skin burns exceed $160 \mathrm{~cm}^{2}$. Fluoride also binds to potassium and magnesium ions leading to myocardial irritation and arrhythmia. Chronic exposure to HF may cause skeletal fluorosis that can be fatal [57-61]. Hemodialysis has been reported to be an effective therapy for cases of severe systemic intoxication [57-61].

\section{Eye injuries}

The eye is highly susceptible to HF liquid or vapor exposures. Contact of HF with eyes may result in permanent eye damage [58-60]. Ocular exposure may denude the cornea and conjunctivae epithelium and lead 
to stromal corneal edema, conjunctivae ischemia, sloughing, and chemosis $[58,59]$. Deeper penetration of the fluoride ion may cause corneal opacification and necrosis of the anterior chamber structures. Usually, the effects are noted within 3 days, although Hatai et al. described a case of delayed corneal damage, it was not apparent until 4 days after the exposure [59]. Latent complications included recurrent corneal epithelial erosions, keratoconjunctivitis sicca, progressive vascularization of the corneal stroma, and symblepharon [58]. As for cutaneous burns, the most important therapy is prompt and efficient lavage. This must be immediate and continued for at least 15-30 min using either water or normal saline [62-66].

Browne advised the use of a few drops of $10 \%$ calcium gluconate after irrigation [62]. Trevino et al. recommended $1 \%$ gluconate in saline as an irrigant followed by $1 \%$ calcium gluconate drops every $2-3 \mathrm{~h}$ for several days [63]. They have reported complete recovery using this treatment in 18 out of 19 patients, of whom 13 had completely opacified corneas prior to treatment [62]. Hatai et al. achieved quick, complete recovery of a large corneal erosion caused by $49 \% \mathrm{HF}$ using a repeated instillation of $1 \%$ calcium gluconate drops combined with conventional treatment [59]. Although others also advised the use $1 \%$ calcium gluconate drops [41, 67], its use remains empirical. McCulley et al. compared irrigation with water, normal saline, magnesium chloride, lanthanum chloride, $0.2 \%$ Hyamine, $0.03 \%$ and $0.05 \%$ Zephiran as well as topical ointments of magnesium oxide and magnesium sulfate [68]. These solutions were also tried as a 1-ml subconjunctival injection. They showed that the only beneficial treatments were irrigation with water, isotonic saline, or isotonic magnesium chloride. Procedures involving repetitive irrigation with these agents caused increased rates of corneal ulceration. The same group has also studied the mechanism of eye injury by HF, demonstrating a clear dose-related response [68]. After irrigation, it is mandatory to request a prompt ophthalmological opinion. Instillation of cycloplegics to dilate the pupil may be required, and some advocate steroid drops to lessen fibroblast formation in the cornea [63, 69]. Rubenfeld et al. are the only group who reported the use of debridement of the sloughing necrotic conjunctiva in an attempt to reduce the fluoride level further and aid in healing [60]. However, speed of delivery of the irrigation remains the most important step among all trials [58].

\section{Inhalation}

Inhalation of low concentrations of HF can cause severe respiratory damage, irritation of the nose, sore throat, lungs, pulmonary edema, burning sensation, cough, dizziness, headache, nausea, shortness of breath, vomiting, and eye/ skin irritation [70, 71]. Animal studies have also showed increased rates of kidney and liver damage as a result of HF inhalation $[42,72-74]$. Anhydrous $\mathrm{HF}$ is very volatile with a boiling point of only $19.5^{\circ} \mathrm{C}$, and even the aqueous solutions (boiling points: $75 \% \mathrm{HF}, 56^{\circ} \mathrm{C} ; 60 \% \mathrm{HF}, 89^{\circ} \mathrm{C}$ ) produce a pungent odor. The recommended level of HF in the working atmosphere should not exceed $3 \mathrm{ppm}$ which could be noticed by smelling [75].

A particular hazard, as noted by Mayer and Guelich, occurs when clothing is contaminated since this can produce high concentrations in the inspired air [70]. They reported the case of three workmen who died of pulmonary complications following splashes to their cotton clothing with $70 \% \mathrm{HF}$, all succumbing within $2 \mathrm{~h}$ of the incident. Dieffenbacher and Thompson also reported about a petroleum worker whose face and neck were in contact with $10 \%$ HF for only $30-35$ s [76]. Despite intravenous and subcutaneous calcium gluconate application, he died $2 \mathrm{~h}$ later. Post-mortem findings showed thick mucus with blood in the bronchi, edematous lungs with hemorrhagic patches, and sub-serous hemorrhages in the pleurae. Greendyke and Hodge described similar post-mortem appearances in two men who died following a serious airway exposure to HF of unspecified concentration [77]. High blood fluoride levels were also present in these patients. Chela and Huguet recorded the murder of a young woman who had thrown HF to her face [78]. She died from acute respiratory insufficiency $3 \mathrm{~h}$ after exposure.

Treatment of inhalational injuries begins with removing the patient immediately from the contaminated area and administering humidified $100 \%$ oxygen as soon as possible. In an attempt to neutralize the fluoride ion, some authorities recommend a nebulized solution of $2.5-3.0 \%$ calcium gluconate [41, 63]. If hemorrhage occurs, then bronchoscopy would be necessary to avoid lobe collapse, and transfusion may also be required [66]. Although corticosteroids have been tried, they should be carefully indicated $[63,79,80]$.

\section{Ingestion}

The first recorded fatality from fluoride poisoning was in 1873 when King reported the case of a 35-year-old man who died within $35 \mathrm{~min}$ after drinking about $15 \mathrm{ml}$ of $\mathrm{HF}$ [81]. This demonstrates the speed of absorption of the fluoride ion by the gastrointestinal tract. Since then, many cases of fluoride poisoning have been recorded due to ingestion [82-90]. Initial symptoms often include nausea, vomiting, and abdominal pain. Ingestion of even relatively dilute solutions of HF may be rapidly fatal.

Management of HF ingestion essentially remains as the dilution, removal, and neutralization of the acid. Stimulation to cause vomiting is not recommended since this may cause further oral, esophageal, or pulmonary injury. The patient should be encouraged to drink either water or preferably milk that has been shown to be effective in 
precipitating fluoride ions in vitro [90]. At the hospital, gastric lavage can be considered and some advise the addition of $10 \%$ calcium gluconate to the lavage fluid [91].

\section{Extreme exposure and death}

$\mathrm{HF}$ at concentrations of 30 parts per million (ppm) is immediately dangerous to life $[70,71]$. Fatalities have been reported from a skin exposure to as little as $2.5 \%$ of body surface area. Once it penetrates the skin, it slowly disassociates into the hydrogen and fluoride ion. The fluoride ion affects tissue integrity and metabolism by liquefaction necrosis, decalcification, destruction of bone, and production of insoluble salts. This will eventually result in loss of calcium from the bones. The development of hypocalcemia can be rapidly fatal because calcium is important for muscles, including cardiac muscle. Without calcium, many metabolic pathways are broken down.

Precautions to avoid HF exposure

\section{Ventilation}

Local exhaust ventilation is generally preferred because it can control the emissions of the contaminant at its source, preventing dispersion of it into the general working area [92]. For emergencies or instances where the exposure levels are not known, the use of a face-piece positivepressure, air-supplied respirator would be useful. It was warned that air-purifying respirators do not protect workers in oxygen-deficient atmospheres [92].

\section{Skin protection}

Protective clothing with long sleeves, air-inflated suits with masks, goggles, including boots or safety shoes with polyvinyl chloride or neoprene should be worn [92].

\section{Eye protection}

Chemical safety goggles and/or full-face shields should be used where splashing is possible. Fountains and quick drench facilities should be maintained in the work area [92].

Summary of major acute and chronic symptoms observed after exposure to HF and the first aid measures are listed in Table 1.

HF use in dentistry and clinical manifestations

\section{HF types and quantities}

Concentrations of HF used in dentistry are usually small, ranging between $5 \%$ and $15 \%$. They are available either in gel or liquid form. It is indicated to be used both in vivo and ex vivo. While the majority of the HF manufacturers for dental use recommend its use with a rubber dam, others provide a gel product, the so-called dental dam to protect adjacent gingival and soft tissues from HF. In order to avoid the likelihood of HF exposure and to make it more visible, coloring dyes are added to make the product red, yellow, or green.

\section{Metals}

The application of HF (7.5\% and 9.5\%) for metals usually takes place in the dental laboratories primarily for stripping and cleaning metals. When a precious metal is cast with a ceramic insert to produce a cylindrical hole that will receive a pin, HF is used to dissolve the ceramic insert to the casting [93].

\section{Ceramics}

The most common use of HF in dentistry is for conditioning glassy-matrix ceramic surfaces to adhere resin-based materials either prior to cementation or during repairs [94-97]. HF selectively etches and dissolves the glass ceramic and cause physical alteration of the surface creating micromechanical retention. The ceramic is then rinsed with water spray. For cementation purposes, HF etched restoration is placed in neutralizing solution of $\mathrm{CaCO}_{3}$ and/or $\mathrm{NaOCl}$. HF gel is further removed in an ultrasonic bath. For intraoral repair applications, ultrasonic cleaning of HF is not possible since the restoration cannot be removed [97]. HF application is then followed by silane coupling agent. Acid concentrations and etching times vary depending on the specifications of the ceramics to receive optimized adhesion of the resin-based material.

\section{Composites}

Although some manufacturers claim that $\mathrm{HF}$ is effective for conditioning resin-based composites also for cementation and repair purposes, poor results were reported [98]. When composites are exposed to $\mathrm{HF}$ acid gel, water monolayer may penetrate via voids to fillers that, in turn, may disorganize the siloxane network formed from the condensation of intermolecular silanol groups, which is responsible for stabilizing the filler-resin interface. For this reason, the use of HF acid gel was not found to be a predictable option for conditioning composite materials for repair or relamination purposes.

\section{Acidulated phosphate fluoride}

The hazards, caustic effects to soft tissues and the danger for clinical use for hydrofluoric acids are well-known by 
Table 1 Major symptoms observed after exposure to hydrofluoric acid and the first aid measures

\begin{tabular}{|c|c|c|}
\hline Hazards & Possible symptoms & First aid ${ }^{\mathrm{a}}$ \\
\hline \multicolumn{3}{|c|}{ Acute hazardous effects } \\
\hline Skin burns & $\begin{array}{l}\text { Redness, pain, blisters, swellings, necrosis } \\
\text { accompanied with pain }\end{array}$ & $\begin{array}{l}\text { Rinse skin with water, calcium gluconate } \\
\text { gel }(2.5 \%) \text { application or calcium luconate } \\
\text { injection, depending on the severity, remove } \\
\text { affected skin }\end{array}$ \\
\hline Nail injuries & Necrotic skin around the nail, indulent ulcer & $\begin{array}{l}\text { Drilling, splitting, or removing nail, immersing } \\
\text { the nail in benzalkonium chloride }\end{array}$ \\
\hline \multicolumn{3}{|c|}{ Chronic hazardous effects } \\
\hline Systemic toxicity & $\begin{array}{l}\text { Painful burn, hypocalcaemia, myocardial } \\
\text { problems, arrhythmia }\end{array}$ & $\begin{array}{l}\text { Immediate transfer to a medical center, } \\
\text { Haemodialysis }\end{array}$ \\
\hline Eye injuries & $\begin{array}{l}\text { Corneal eudema, conjuctivae ischemia, delayed } \\
\text { corneal damage, keratoconjuctivitis sicca, } \\
\text { vascularization of the corneal stroma }\end{array}$ & $\begin{array}{l}\text { Efficient lavage }(15-30 \mathrm{~min}) \text { with water or } \\
\text { isotonic saline followed by application of } \\
\text { calcium gluconate drops, consulting an } \\
\text { ophthalmologist }\end{array}$ \\
\hline Inhalation & $\begin{array}{l}\text { Irritation of the nose, sore throat, lungs, burning } \\
\text { sensation, cough, dizziness, headache, nausea, } \\
\text { shortness of breath, vomiting, eye, skin, } \\
\text { pulmonary edema, possible kidney, liver } \\
\text { damage, hypocalcemia, death }\end{array}$ & $\begin{array}{l}\text { Immediate transfer to a medical center, removing } \\
\text { the subject from the contaminated area, } \\
\text { nebulized solution of calcium gluconate } \\
\text { depending on the severity bronchoscopy, } \\
\text { transfusion }\end{array}$ \\
\hline Ingestion & Nausea, vomiting, and abdominal pain & Drink water, milk, gastric lavage \\
\hline
\end{tabular}

${ }^{\mathrm{a}}$ In all cases, a doctor should be consulted

the manufacturers and the researchers. For this reason, some studies questioned whether $1.23 \%$ acidulated phosphate fluoride gels might serve as a safe and effective substitute for etching ceramic surfaces to bond composite resin to silanized ceramics [99-101]. It was concluded that $1.23 \%$ acidulated phosphate fluoride gels can substitute 9.5\% HF but prolonged etching times were required with the lower concentrations of HF [102]. However, the specimens etched with $4 \%$ acidulated phosphate fluoride gel, showed a wider statistical spread than the ones etched with $9.6 \% \mathrm{HF}$. This suggested that HF etching might well produce a more reliable and consistent result but this has not been confirmed, as the sample size of these studies was too small $[100,102]$.

\section{Topical fluoride rinses and gels}

Therapeutic fluoride products are also applied on teeth for preventive purposes especially in pediatric dentistry. However, $\mathrm{HF}$ is a minor ingredient in topical therapeutic fluoride. Necessary precautions should still be considered using a rubber dam during their application.

\section{Concluding remarks}

Since no incidence on hazardous effects of HF has been reported in the dental literature, this literature review led to the conclusion that risks of in vivo and ex vivo use of HF, considering the concentrations used in dentistry appears to be unwarranted. Since repair actions are rather seldom, particularly the clinicians who indicate glass ceramic restorations would be more likely to be exposed to $\mathrm{HF}$ during cementation procedures. Concentrated solutions cause immediate pain and produce a surface burn similar to other common acids with erythematic responses, blistering, and necrosis [52]. HF concentrations of $14.5 \%$ produce symptoms immediately and concentrations of $12 \%$ may take up to an hour. Reaction to exposure of $7 \%$ HF or less, may take several hours before onset of symptoms, resulting in delayed symptoms with the deeper penetration of the HF. For occupational exposure, American Conference of Industrial Hygienists reported the lowest limits by giving a maximum value (a limit that should never be exceeded for even an "instantaneous" exposure period of $3 \mathrm{ppm} ; 2.3 \mathrm{mg} / \mathrm{m}^{3}$ ) [103]. This exposure limit ( $3 \mathrm{ppm})$ has also been given as $8 \mathrm{~h}$ time weighed average level by the Occupational Safety and Health Administration [103]. On the other hand, the National Institute of Occupational Safety and Health considered Dangerous To Life and Health value as $30 \mathrm{ppm}$ [103]. Taking these values into account, for the dental professionals and patients, a risk analysis could be performed based on the frequency of the use of HF. Due to the continuous use of HF in dentistry, the patients should be monitored even after cementation or fixation of the restorations. Knowing potential hazards of HF from other 
fields, media other than HF gel have certainly potential in the future for conditioning ceramic surfaces in dentistry.

Acknowledgments The authors thank to Assoc. Prof. Dr. H.G. Orhan, Ege University, School of Pharmacy, Department of Toxicology, Izmir, Turkey, for the helpful discussion and comments regarding to toxicity.

Conflict of interest The authors declare that they have no conflict of interest.

\section{References}

1. Litovitz TL, Klein-Schwartz W, Dyer KS, Shannon M, Lee S, Powers M (1998) 1997 Annual Report of the American Association of Poison Control Centers Toxic Exposure Surveillance System. Am J Emerg Med 16:443-497

2. Litovitz TL, Klein-Schwartz W, Caravati EM, Youniss J, Crouch B, Lee S (1999) 1998 Annual Report of the American Association of Poison Control Centers Toxic Exposure Surveillance System. Am J Emerg Med 17:435-487

3. McClure FJ (1933) Review of fluorine and its physiological effects. Physiol Rev 13:277-300

4. Fact Sheet Environment: Health \& Safety information for the Berkley Campus. Division of Industrial Hygiene, National Institute of Health (1943) Hydrofluoric acid burns. Indust Med 12:634-637

5. Shewmake SW, Anderson BG (1979) Hydrofluoric acid burns. A report of a case and review of the literature. Arch Dermatol 115:593-596

6. Calamia JR (1989) Clinical evaluation of etched porcelain veneers. Am J Dent 2:9-15

7. Diaz-Arnold AM, Schneider RL, Aquilino SA (1989) Bond strengths of intraoral porcelain repair materials. J Prosthet Dent 61:305-309

8. Özcan M, Pfeiffer P, Nergiz I (1998) A brief history and current status of metal/ceramic surface conditioning concepts for resin bonding in dentistry. Quintessence Int 29:713-724

9. Caravati EM (1988) Acute hydrofluoric acid exposure. Am J Emer Med 6:143-150

10. Bertolini JC (1992) Hydrofluoric acid: a review of toxicity. J Emer Med 10:163-168

11. Harris JC, Rumack BH, Bregman DJ (1981) Comparative efficacy of injectable calcium and magnesium salts in the therapy of hydrofluoric acid burns. Clin Toxicol 18:1027-1032

12. Dunn B, MacKinnon MA, Knowlden NF, Billmaier DJ, Derelanko MJ, Rusch GM (1996) Hydrofluoric acid dermal burns: an assessment of treatment efficacy using an experimental pig model. J Occup Environ Med 38:507-514

13. Gallerani M, Bettoli V, Peron L, Manfredini R (1998) Systemic and topical effects of intradermal hydrofluoric acid. Am J Emer Med 16:521-522

14. Doyle I (1989) Treatment of hydrofluoric acid exposure. J Occup Med 30:52-63

15. Klauder JV, Shelanski L, Gabriel K (1955) Industrial uses of compounds of fluorine and oxalic acids. Arch Indust Health $12: 412-419$

16. Janzekovic Z (1970) A new concept in skin grafting of burns. J Traumatol 10:1103-1108

17. Reynolds KE, Whitford GB, Pashley DH (1978) Acute fluoride toxicity: the influence of acid base status. Toxicol App Pharmacol 45:415-427
18. McIvor ME (1990) Acute fluoride toxicity: pathophysiology and management. Drug Saf 5:79-85

19. Whelanski RH (1990) Hydrofluoric acid bums of the skin. J Hand Surg 15:52-63

20. Paterson JD (1956) Control of the fluorine hazard. Brit J Indust Med 16:301-303

21. Henry JA, Hla KK (1992) Intravenous regional calcium gluconate perfusion for hydrofluoric acid burns. J Toxicol Clin Toxicol 30:203-207

22. Jones AT (1939) The treatment of hydrofluoric acid burns. J Ind Hyg Toxicol 2:205-212

23. Chick LR, Borah G (1990) Calcium carbonate gel therapy for hydrofluoric acid burns of the hand. Plast Recons Surg 86:935-940

24. Henry JA, Hla KK (1992) Intravenous regional calcium gluconate perfusion for hydrofluoric acid burns. Clin Toxicol 30:203-207

25. Burkhart KK, Brent J, Kirk MA, Baker DC, Kulig KW (1994) Hydrofluoric acid burns. Ann Emer Med 23:110-121

26. Cox RD, Osgood KA (1994) Evaluation of intravenous magnesium sulphate for the treatment of hydrofluoric acid burns. J Toxicol Clin Toxicol 32:123-136

27. Graudins A, Burns MJ, Aaron CK (1997) Regional intravenous infusion of calcium gluconate for hydrofluoric acid burns of the upper extremity. Ann Emer Med 30:604-607

28. Yasuda H, Honda S, Yamamoto O, Asahi M (1999) Therapeutic effect of topical calcium gluconate for hydrofluoric acid burntime limit for the start of treatment. J Occup Med 21:209-216

29. Aguilera IM, Vaughan RS (2000) Calcium and the anaesthesist. Anaesthesia 55:779-790

30. Yamashita M, Suzuki M, Hirai H, Kajigaya H (2001) Iontophoretic delivery of calcium for experimental hydrofluoric acid burns. Crit Care Med 29:1575-1578

31. Vance MV, Curry SC, Kunkell DB, Ryan PJ, Ruggeri SB (1986) Digital hydrofluoric acid burns: treatment with intra-arterial calcium infusion. Ann Emer Med 15:890-896

32. Roberts JR, Merigian KS (1988) Acute hydrofluoric acid exposure. Am J Emer Med 7:125-126

33. Burkhart KK, Brent J, Kirk MA, Baker DC, Kulig KW (1995) Comparison of topical magnesium and calcium treatment for dermal hydrofluoric acid bums. Ann Emer Med 21:9-13

34. Aaron CK, Burns MJ, Graudins A (1997) Regional intravenous infusion of calcium gluconate for hydrofluoric acid burns of the upper extremity. Ann Emer Med 30:604-607

35. Dale RH (1951) Treatment of hydrofluoric acid burns. Brit Med J 1:728-732

36. Craig RDP (1964) Hydrofluoric acid bums. Brit J Plas Surg 17:52-59

37. Schwamweber HC (1969) Treatment of hydrofluoric acid burns of the skin by immediate surgical excision. Indust Med 38:31-32

38. Tschantz P, Favre H (1975) Necrotizing pancreatitis after formic acid and hydrofluoric acid burns. Schweiz Rundsch Med Prax 64:487-490

39. Kohnlein HE, Achinger R (1982) A new method of treatment of hydrofluoric acid burns of the extremities. Chirurgie Plast 6:297-305

40. Velvart J (1983) Arterial perfusion for hydrofluoric acid bums. Human Exposure Toxicol 2:233-238

41. MacKinnon MA (1986) Treatment of hydrofluoric acid burns. J Occup Med 28:804

42. Wing JS, Brender JD, Sanderson LM, Perrotta DM, Beauchamp RA (1991) Acute health effects in a community after a release of hydrofluoric acid. Arch Environ Health 46:155-160

43. Morris JB, Smith JA (1982) Regional deposition and absorption of inhaled hydrogen fluoride in the rat. Toxicol App Pharmacol 62:81-89

44. Lewis GK (1959) Chemical burns. Am J Surg 98:928-937 
45. Hamilton M (1975) Hydrofluoric acid burns. Occup Health $27: 468-470$

46. Edelman P (1986) Hydrofluoric acid burns. Occup Med 1:89103

47. Chan KM, Svancarek WP, Creer M (1987) Fatality due to acute hydrofluoric acid exposure. J Clin Toxicol 25:333-339

48. Wilkes GJ (1993) Intravenous regional calcium gluconate for hydrofluoric acid burns of the digits. Emer Med 5:155-158

49. McIvor ME, Cummings CE, Mower MM (1987) Sudden cardiac death from acute fluoride intoxication: the role of potassium. Ann Emer Med 16:777-781

50. Mullett T, Zoeller T, Bingham H, Pepine CJ, Prida CX, Castenholz R, Kirby R (1987) Fatal hydrofluoric acid cutaneous exposure with refractory venticular fibrillation. J Burn Care Rehabil 2:216-219

51. Muriale L, Lee E, Genovese J, Trend S (1996) Fatality due to acute fluoride poisoning following dermal contact with hydrofluoric acid in a palynology laboratory. Ann Occup Hyg 40:705710

52. Mayer TG (1998) Hydrofluoric acid burns. Am J Emer Med $32: 116-127$

53. Waldbott GL (1963) Acute fluoride intoxication. Acta Med Scand $174: 5-44$

54. Tepperman PB (1980) Fatality due to acute systemic fluoride poisoning following a hydrofluoric acid skin burn. J Occup Med 22:691-692

55. Mayer TG, Gross PL (1985) Fatal systemic fluorosis due to hydrofluoric acid burns. Am J Emer Med 14:149-153

56. Chela A, Reig R, Sanz P, Huguet E, Corbella J (1989) Death due to hydrofluoric acid. Am J For Med Pathol 10:47-48

57. Watson AA, Oliver JS, Thorpe JA (1973) Accidental death due to inhalation of hydrofluoric acid. Med Sci Law 13:277-279

58. McCulley JP, Whiting DW, Petitt MG, Lauber SE (1983) Hydrofluoric acid bums of the eye. J Occup Med 25:447-450

59. Hatai JK, Weber JN, Doizaki K (1986) Hydrofluoric acid bums of the eye: report of possible delayed toxicity. J Toxicol Cut 5:179-184

60. Rubenfeld RS, Silbert DI, Arentsen JJ, Laibson PR (1992) Ocular hydrofluoric acid bums. Am J Ophthalmol 114:420-423

61. Chan BS, Duggin GG (1997) Survival after massive hydrofluoric acid ingestion. J Toxicol Clin Toxicol 35:307-310

62. Browne TD (1974) The treatment of hydrofluoric acid bums. J Occup Med 24:80-89

63. Trevino MA, Herrmann GH, Sprout WI (1983) Treatment of severe hydrofluoric acid exposures. J Occup Med 25:861-863

64. MacKinnon MA (1988) Hydrofluoric acid burns. Dermatol Clin 6:67-74

65. Zoeller T, Bingham H, Pepine CJ (1989) Hydrofluoric acid burns. J Burn Care Rehabil 35:16-19

66. Upfal M, Doyle C (1990) Medical management of hydrofluoric acid exposure. J Occup Med 32:726-731

67. Pegg SP, Siu S, Gillett G (1985) Intra-arterial infusions in the treatment of hydrofluoric acid burns. Burns 2:440-443

68. McCulley JP (1990) Ocular hydrofluoric acid burns: animal model, mechanism of injury and therapy. Trans Am Ophthalmol Soc 88:649-684

69. Vaughn D, Asbury T (1983) General Ophthalmology. Los Altos, California: Lange 39.

70. Mayer L, Guelich J (1963) Hydrogen fluoride inhalation and bums. Arch Environ Health 7:445-447

71. Vance MV, Curry SC, Kunkel DB (1983) Treatment of hydrofluoric acid burns. Emer Med 17:15-56
72. Morris JB, Smith FA (1978) Regional deposition and absorption of inhaled hydrogen fluoride. Toxicol App Pharmacol 45:415427

73. Braun J, Stoss H, Zober A (1984) Intoxication following inhalation of hydrogen fluoride. Arch Toxicol 56:50-54

74. Kono K, Yoshida Y, Watanabe M (1992) Serum fluoride as an indicator of occupational hydrofluoric acid exposure. Inf Arch Occup Environ Health 64:343-346

75. Sevitt S (1957) Burns: pathology and therapeutic applications. Butterworth, London, pp 330-333

76. Dieffenbacher PF, Thompson JH (1996) Burns from exposure to anhydrous hydrofluoric acid. J Occup Med 4:325-326

77. Greendyke RM, Hodge HC (1964) Accidental death due to hydrofluoric acid. J Foren Sci 9:383-390

78. Chela A, Huguet E (1987) Hydrofluoric acid burns. Am J Foren Med 5:87-110

79. Iverson RE, Laub DR, Madison MS (1988) A radical approach to severe hydrofluoric acid burns. A case report. J Occup Med 30:873-874

80. Foster DE, Barone JA (1989) Rectal hydrofluoric acid exposure. Clin Pharmacol 8:516-518

81. King R (1973) Poisoning by hydrofluoric acid. Trans Pathol Sot 24:98-100

82. McNally WD (1923) Four deaths caused by sodium fluoride. J Am Med Assoc 23:811-813

83. Fullerton WW (1930) Two rather uncommon fatal cases of poisoning. N Eng J Med 203:423

84. Maletz L (1935) Report of a fatal case of fluoride poisoning. N Eng J Med 213:370-372

85. Greenwood DA (1940) Fluoride intoxication. Physiol Rev 20:582-616

86. Lidbeck WL, Hill IB, Beeman JA (1943) Acute sodium fluoride poisoning. J Am Med Assoc 121:826-827

87. Rabinowitch IM (1945) Acute fluoride poisoning. Canad Med Assoc 52:345-349

88. Waldbott GL (1959) Urticaria due to fluoride. Acta Allerg $13: 456-468$

89. Siedlecki JT (1965) Hydrofluoric acid burns. Questions and answers. J Am Med Assoc 191:353

90. Yolken R, Konecuy P, McCarthy P (1976) Acute fluoride poisoning. Paediatrics 58:90-93

91. Satremski ES, Grande GA, Ling LJ (1992) Survival following hydrofluoric acid ingestion. Am Emer Med 21:1396-1399

92. Catton V (1983) Prevention and treatment of hydrofluoric acid burns. Occup Health 35:227-231

93. Wood DJ, Bubb NL, Millar BJ, Dunne SM (1997) Preliminary investigation of a novel retentive system for hydrofluoric acid etch-resistant dental ceramics. J Prosthet Dent 78:275-280

94. Calamia JR (1985) Etched porcelain veneers: the current state of the art. Quintessence Int 1:5-12

95. Stangel I, Nathanson D, Hsu CS (1987) Shear strength of the composite bond to etched porcelain. J Dent Res 66:1460-1465

96. Thurmond JW, Barkmeier W, Wilwerding TM (1994) Effect of porcelain surface treatments on bond strengths of composite resin bonded to porcelain. J Prosthet Dent 72:355-359

97. Özcan M (2003) Evaluation of alternative intraoral repair techniques for fractured ceramic-fused-to- metal restorations. J Oral Rehabil 30:194-203

98. Özcan M, Alander P, Vallittu PK, Huysmans MC, Kalk W (2005) Effect of three surface conditioning methods to improve bond strength of particulate filler resin composites. J Mater Sci Mater Med 16:21-27 
99. Sposetti V, Shen C, Levin A (1986) The effect of topical fluoride application on porcelain restorations. J Prosthet Dent 55:677-686

100. Lacy AM, Laluz J, Watanabe LG, Dellinges M (1988) Effect of porcelain treatments on the bond strength of composite. J Prosthet Dent 60:288-292

101. Della Bona A, Van Noort R, Sear VS (1995) Tensile bond strength of resin composite bonded to ceramic. J Dent Res $74: 1591-1596$
102. Brentel AS, Özcan M, Valandro LF, Alarça LG, Amaral R, Bottino MA (2007) Microtensile bond strength of a resin cement to a feldspathic ceramic after different etching and silanization regimens in dry and aged conditions. Dent Mater 23:1323-1331

103. Threshold Limit Values (TLVs) for Chemical Substances and Physical Agents and Biological Exposure Indices $\left(B E I{ }^{\circledR}\right)$, American Conference of Governmental Industrial Hygienists, Inc., p 42. Cincinnati, Ohio, 2005. http://www.osha.gov 2005 